\title{
THE RIGHT TO MOTHER-TONGUE EDUCATION: PRACTICABLE OR NOT?
}

\author{
Chrizell Chürr \\ LLB LLM LLD \\ Senior Lecturer, Faculty of Law \\ University of South Africa (UNISA)
}

\section{SUMMARY}

Mother-tongue and mother-tongue education are recognized worldwide as one of the most efficient ways to function cognitively and socially. This article addresses the role of proper mother-tongue education with an emphasis on the importance of "language" since language is vital to a child's right to a basic education in all its dimensions. Without mother-tongue education, every child's right to learn and to become a skilful adult, able to participate independently in society, is at risk. The cumulative effect of the South African Constitution, the National Education Policy Act, the South African Schools Act, several international instruments and a number of ground-breaking cases, as well as the interaction between them on mother-tongue education will be examined. The implementation of certain education models will also be proposed.

"Hulle praat Afrikaans by die huis, maar hul kinders moet liefs na Engelse skole toe gaan, omdat Engels 'n wêreldtaal is en dit kinders se kanse op sukses glo eendag sal bevorder. Dít, terwyl daar wêreldwyd al hoe meer stemme ten gunste van moedertaalonderrig opgaan omdat die meeste navorsing op die voordele hiervan wys."

\section{INTRODUCTION}

Mother tongue is recognized worldwide as one of the most efficient ways to function cognitively and socially. Mother tongue is invaluable for personal and cultural identity, as well as for intellectual and emotional development. Mother tongue starts at birth and continues throughout life, and it is therefore important for children to be educated and instructed in their mother tongue. ${ }^{2}$

However, the issue of mother-tongue education in South Africa remains a problematic one. On the one hand, it appears to be reasonable, acceptable and enviable to provide learners with education in their mother tongue if they

Rademeyer "Taal van die Skoolbanke" September 2005 Taalgenoot 22.

2 Gabela "Language of Education in South Africa" http://www.deta.up.ac.za/archive2007/ presentations/word/language\%20of\%20education\%20Gabela\%20RV.pdf, accessed 201205-11. 
wish to receive mother-tongue education. Conversely, there are some obstacles and challenges in the implementation of this "mother tongue education" ideal. ${ }^{3}$

Along with this problematic issue, is the dilemma relating to the skills and ability of learners when the use of English as the primary medium of instruction is preferred. ${ }^{4}$ Presently, English enjoys recognition nationally and internationally. Consequently, English is the language in which most South Africans prefer their children to be educated. Most parents are convinced that it is to the advantage of their children to be "English-dominant" since the English language will ease their children's access to training, work possibilities and economic freedom, and provide a stepping stone into the international arena. ${ }^{5}$ The preference given to English as the primary medium of instruction results in a situation where almost all learners will receive their education through the medium of English, while these learners - and sometimes teachers as well - are not capable and skilful enough to use English as a second language (and sometimes as a third language) in teaching and learning. Moreover, the value and quality of teaching and learning also become debatable. ${ }^{6}$

The motto of the South African Coat of Arms is: "Ike e: /xarra //ke" which means "Unity in Diversity". One can thus argue that the current focus on English as a primary medium of teaching and learning constitutes the unity, and the principle of diversity is overlooked, which results in "no support for the provisioning of quality education to all".

The discussion of mother-tongue education is important because language is vital to a child's right to a basic education in all its dimensions. Language is the way in which access to learning and education is made possible. Language is the end product of proper education, and language has a tremendous influence and impact on the quality and final outcome for learners individually and collectively. Language is of cardinal importance with regard to the identity of people and it is in itself a right and a way of identifying and observing the world. Furthermore, language is the foundation of self-knowledge, confidence and self-respect. ${ }^{8}$

Thus, without mother-tongue education, every child's right to learn and to become a skilful adult, able to participate independently in society, is at risk. ${ }^{9}$

This article consists of an in-depth discussion of mother tongue language, mother-tongue education and the importance thereof. The most important

3 Foley "Mother-tongue Education in South Africa" http://www.englishacademy.co.za/pansalb/ education.pdf, accessed 2012-05-11.

Gabela, see fn 2 above.

5 Louwrens "Moedertaalonderrig as moderator by die Verband tussen Intelligensiekwosient en Akademiese Prestasie" http://etd.uovs.ac.za/ETD-db/theses/submitted/etd-08262004170956/unrestricted/02Louwrens.pdf, accessed 2012-05-11.

6 Steyn et al "'Unity in diversity' in South African education: inciting ideas from Europe" 2007 SA-educ Journal 2.

Ibid.

8 Le Mottee "Language in Education" http://www.osisa.org/.../2_3_language_p032-038_sher ri_le_mottee.pdf, accessed 2012-05-09.

9 Ibid. 
areas with regard to mother-tongue education in South Africa are discussed under the headings of: Language - a fundamental right; Language policy of South Africa; and the Pan South African Language Board. Different forms of language education and the importance of bilingual education and mothertongue-based multilingual education is also emphasised. The most important international instruments, national legislation and several groundbreaking cases pertaining to mother-tongue education will also be discussed. It will be concluded that the implementation of certain education models will be invaluable to the promotion and advancement of mother-tongue education.

\section{LANGUAGE: A FUNDAMENTAL RIGHT}

Language is a fundamental right, and the South African Constitution makes provision for the protection and promotion of the eleven official languages.

Section 6 of the Constitution stipulates that the official languages of the Republic of South Africa are Sepedi, Sesotho, Setswana, siSwati, Tshivenda, Xitsonga, Afrikaans, English, isiNdebele, isiXhosa and isiZulu. The Constitution stipulates that affirmative action must be taken with regard to the African languages that were marginalized in the past: These languages "must enjoy parity of esteem and must be treated equitably". It further states that the state has the obligation to take practical and positive measures to elevate the status and advance the use of these languages. ${ }^{10}$

In terms of section 9 of the Constitution, everyone is equal before the law and has the right to equal protection and benefit of the law. It also states that no one may discriminate unfairly directly or indirectly against anyone on one or more grounds, including language.

Section 29(2) states that everyone has the right to receive education in the official language or languages of his/her choice in public educational institutions where that education is reasonably practicable. Section 30 of the Constitution provides that everyone has the right to use the language and to participate in the cultural life of his/her choice. In terms of section 31 of the Constitution, persons belonging to a cultural, religious or linguistic community may not be denied the right, with other members of that community, to enjoy their culture, practice their religion and use their language, and these persons have the right to form, join and maintain cultural, religious and linguistic associations and other organs of civil society.

Section 35(3)(k) states that every accused person has a right to a fair trial, which includes the right to be tried in a language that the accused person understands or, if that is not practicable, to have the proceedings interpreted in that language.

It is thus clear from the above that the use of any language for the purposes of exploitation, domination or separation should be avoided. In short: South Africa has a diversity of languages and cultures and these

10 See in general, Beukes "The First Ten Years of Democracy: Language Policy in South Africa" http://www.linguapax.org/congres04/pdf/1_beukes.pdf, accessed 2012-05-11. 
diversities must be recognized and protected, and the promotion of mother tongue should always be encouraged. ${ }^{11}$

\section{LANGUAGE POLICY IN SOUTH AFRICA}

\section{Language management}

Language policy in South Africa is managed at three levels of governance, namely at the national, provincial and local government level. ${ }^{12}$

\section{National level}

The responsibility of language management is attributed to: the Minister of Arts and Culture who is responsible for macro language policy matters; the Minister of Education who is responsible for language-in-education policy; the Minister of Communications who is responsible for language policy relating to the public broadcaster; and the Minister of Justice and Constitutional Development who is responsible for all language matters in the courts.

\section{Provincial level}

There is an obligation on all nine provincial governments to manage and administer their own language matters, which includes the customization of language policies to regional circumstances, needs and preferences.

\section{Local government level}

Municipalities have the responsibility to develop language policies that are well-matched with the applicable provincial policy. The language usage and preferences of all residents within the municipality district must also be taken into consideration.

\section{Language policy in schools}

Section 29(2) of the Constitution stipulates that everyone has the right to receive education in the official language or languages of their choice in public educational institutions where that education is reasonably practicable.

Section 3(1) of the National Education Policy Act ${ }^{13}$ states that the Minister shall determine national education policy in accordance with the provisions of the Constitution and this Act. Moreover, section 4(a)(v) stipulates that the policy contemplated in section 3 shall be directed toward the advancement

11 Departement van Nasionale Opvoeding Suid-Afrika se Nuwe Taalbeleid - Die Feite (1995) 3.

12 Beukes see fn 10 above.

1327 of 1996. 
and protection of the fundamental rights of every person guaranteed as stipulated in Chapter 3 of the Constitution, and in terms of international conventions ratified by Parliament, and in particular the right of every student to be instructed in the language of his or her choice where this is reasonably practicable.

Section 6 of the South African Schools Act ${ }^{14}$ states that subject to the Constitution and this Act, the Minister may, by notice in the Government Gazette, after consultation with the Council of Education Ministers, determine norms and standards for language policy in public schools. The governing body of a public school may determine the language policy of the school subject to the Constitution, this Act and any applicable provincial law. It further states that no form of racial discrimination may be practised in implementing policy determined under this section.

The aforementioned legislation emphasizes the crucial importance of language, and it is on the basis of this legislation that the Language in Education Policy (LiEP) provides for the following: Schools are permitted to adopt either one language (mother tongue) as a medium of instruction or two languages (mother tongue in the early grades and a second language in the senior phases). ${ }^{15}$ The LiEP further states that: ${ }^{16}$

"Whichever route is followed, the underlying principle is to maintain home language(s) while providing access to and the effective acquisition of additional language(s)."

The National Curriculum Statement also suggests that "the learner's home language should be used for learning and teaching wherever possible. This is particularly important in the Foundation Phase where children learn to read and write".

\section{THE PAN SOUTH AFRICAN LANGUAGE BOARD (PANSALB)}

As already mentioned, the state has an obligation to ensure that the African languages that were marginalized in the past now enjoy parity of esteem and equal treatment. In this regard a national body, namely the Pan South African Language Board (PanSALB), ${ }^{18}$ was established to ensure that all official languages, including the ancient indigenous languages of the Qoi (Khoi), San and Nama are developed and promoted. ${ }^{1}$

One can thus see that high priority is given to the development and promotion of all the official languages in South Africa. The Constitution also emphasizes the importance of the development and promotion of all the official languages. Section 6(4) of the Constitution states as follows:

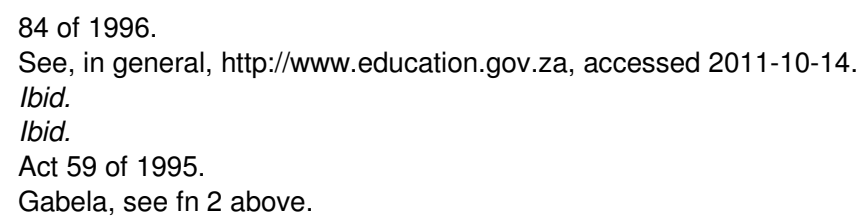


"The national government and provincial governments, by legislative and other measures, must regulate and monitor their use of official languages.... All official languages must enjoy parity of esteem and must be treated equitably."

The importance of PanSALB is also emphasized in section 6(5) of the Constitution which stipulates as follows:

"A Pan South African Language Board established by national legislation must

(a) promote, and create conditions for, the development and use of -

(i) all official languages;

(ii) the Khoi, Nama and San languages; and

(iii) sign language ..."

It is thus evident from section 6 of the Constitution that Sign Language is recognized as an official language of South Africa. Thus, a recognized Sign Language for hearing impaired children will also enjoy the status of an official language relating to learning at a public school.

\section{DIFFERENT FORMS OF LANGUAGE EDUCATION}

\section{Mother-tongue education}

\section{Definition of mother tongue language}

According to UNESCO, mother tongue can be defined as "the language(s) that one has to learn first; the language(s) one identifies with or is identified as a native speaker of by others; the language(s) one knows best and the language one uses the most".

The definition of mother tongue language can also be tabulated as follows: ${ }^{21}$

\begin{tabular}{|l|l|}
\hline \multicolumn{1}{|c|}{ CRITERION } & \multicolumn{1}{c|}{ DEFINITION } \\
\hline ORIGIN: & the language one learned first \\
\hline $\begin{array}{l}\text { IDENTIFICATION: } \\
\begin{array}{l}\text { (a) Internal } \\
\text { (b) External }\end{array}\end{array}$ & $\begin{array}{l}\text { (a) the language one identifies with } \\
\text { (b) language one is identified as a } \\
\text { native speaker of by others }\end{array}$ \\
\hline COMPETENCE: & the language one knows best \\
\hline FUNCTION: & the language one uses most \\
\hline
\end{tabular}

20 Bray "The South African Schools Act" in Boezaart (ed) Child Law in South Africa (2009) 481.

21 Skutnabb-Kangas Linguistic Genocide in Education - Or Worldwide Diversity and Human Rights (2000) 105-115. 


\section{The importance of mother-tongue education}

"As jy nie jou eie taal ken nie, is dit net so goed jy weet nie wie jy is nie."22

Mother tongue is the most effective language for initial instruction and learning; this can be justified from different perspectives: ${ }^{23}$

- From a psycholinguistic perspective, mother tongue is cognitively the best for expression and reception.

- From a sociolinguistic perspective, mother tongue is a vital instrument for the identification of the relevant respective community/society.

- From an educational perspective, a child will learn the best through mother tongue as primary medium of instruction.

Hence, children who enter primary school will certainly learn best through their mother tongue, and a second language (such as English) will be acquired without difficulty if the child already has a solid understanding, insight and knowledge of his or her home language or mother tongue. It can therefore be argued that one of the contributing factors to the "poorthroughput-rates problem" in South African schools is the use of a second language as the primary medium of instruction. ${ }^{24}$

Already in 1951, a UNESCO meeting of experts advised "on educational grounds, that the use of mother tongue instruction be extended to as late a stage in education as possible. In particular, pupils should begin their schooling through the medium of mother-tongue". ${ }^{25}$ In addition to the aforementioned, the following three principles with regard to language in education are of cardinal importance: ${ }^{26}$

- Mother-tongue instruction is a way in which education quality is improved by building upon the existing knowledge base of learners and teachers;

- bilingual and multilingual education promote and advance social and gender equality and is a vital component of linguistically diverse societies;

- language is an invaluable component of intercultural education, since it cultivates and encourages a greater understanding between different population groups and ensures respect for fundamental rights.

In short, if children are taught and instructed in a language that they understand, they have a better chance of academic prowess and success. On another important level, the use of mother-tongue instruction relates to self-actualization, which refers to the fulfilling of one's individual potential. It is thus eminent that if schools offer mother tongue based bilingual education,

22 Dugmore "Van Mikro tot Moedertaalonderrig" http://vryeafrikaan.co.za/site/lees.php?id=835, accessed 2012-05-11.

23 Louwrens, see fn 5 above.

24 Foley, see fn 3 above.

25 Le Mottee, see fn 8 above.

26 Ibid. 
children will develop in the best way possible and they will become fulfilled individuals. $^{27}$

\section{Arguments in support of mother-tongue education}

There are several arguments that support the importance of mother-tongue education: ${ }^{28}$

- Mother-tongue education facilitates the changeover from home to school, and the school is integrated into society in a positive way.

- Mother-tongue education improves and strengthens the cardinal importance of localized language and identity.

- Emphasis must be given to the fact that mother tongue is the primary carrier of cultural identity.

- Linguistic and cognitive development is facilitated through mother tongue.

- Reading is one of the most important skills a child should master during his or her first school years. Research has shown that a child's progress with regard to the reading process is built on mother tongue.

- It is also important to remember that a child's "way of thinking" develops through language. Language confusion can therefore have detrimental effects on a child's "way of thinking".

The following educational arguments support mother-tongue education: ${ }^{29}$

- Mother-tongue education facilitates the acquisition of knowledge and concept/idea, as well as the development of cognitive, affective and social skills in accordance with learners' potential.

- The use of mother tongue as a primary medium of instruction promotes the development of learners' language proficiency.

- The social, psychological and cultural functions of language are of vital importance in any teaching situation.

\section{A practical example of the importance of mother-tongue education}

The following set of facts provides a clear example of the importance of mother-tongue education:

All grade-7 learners in South African schools were obliged to write a "national science examination paper". This paper was available in Afrikaans and English. The results were disappointing, and it was clear that the learners who wrote the paper in Afrikaans, performed better than those who wrote the paper in English.

Dugmore, see fn 22 above.

Louwrens, see fn 5 above.

29 Webb "Perspektiewe op Moedertaalonderrig" June 2006 Tydskrif vir Geesteswetenskappe 39-40. 
The reason for the above is simple: One can presume that the learners, who wrote the paper in Afrikaans, had the advantage of writing in their mother tongue. Conversely, many of the learners had to write the paper in English and did not have the advantage of writing in their mother tongue, since English is in most instances a second (or sometimes even a third) language and learners are sometimes challenged to understand, read and write difficult concepts in a second language.

Professor Irma Eloff once said that "moedertaalonderrig het duidelik 'n positiewer effek op kinders se selfvertroue en volgehoue prestasie as dié van hul maats wat hul skoollewe in " $\mathrm{n}$ nuwe taal moes aanpak". ${ }^{30}$ I fully agree with professor Eloff, since it is desirable and to the advantage of all children to be instructed in their mother tongues for as long as possible.

\section{Challenges in the way of mother-tongue education}

The promotion of mother-tongue education is hampered by several factors: ${ }^{31}$

- Ignorance with regard to the advantages of mother-tongue education.

- The negative social meaning which is given to African languages and Afrikaans.

- The social and economic power of English.

- Difficulties with the practical implementation of mother-tongue education in linguistically diverse communities.

Despite these challenges, South Africa is still capable of creating favourable teaching environments and promoting mother-tongue education, since there is strong national legislation which makes provision for the promotion and advancement of mother-tongue education. However, in order to promote mother-tongue education, it is important to implement approaches such as bilingual education ${ }^{32}$ and MT-based MLE $^{33}$ where reasonably possible and practicable. The implementation of "new approaches" will definitely not be without difficulties, but at least the importance of mother-tongue education will not be suppressed.

\section{Bilingualism (Bilingual education)}

"Since a bicycle has two wheels and binoculars are for two eyes, it would seem that bilingualism is simply about two languages."

30 See, in general, Dippenaar "Moedertaal Beslis Beste Medium vir Onderrig" May 2010 Burger 4.

31 Webb 2006 Tydskrif vir Geesteswetenskappe 45-46.

32 See par 52 below.

33 See par 53 below.

34 Baker Foundations of Bilingual Education and Bilingualism 5ed (2011) 2. 


\section{Definition}

Bilingual education can be defined as the instruction or teaching of academic content in two languages: a home language (mother tongue) and a secondary language where varying amounts of both languages are used in accordance with the relevant programme model.

According to Snayers and Du Plessis, the term bilingual education can be defined as "die gebruik van twee tale in die onderrig van 'n individuele leerder". ${ }^{35}$ Thus, the two languages are not only "subjects", but are also used to teach "subject content".

\section{Is bilingual education to the advantage of learners?}

There is no way that bilingualism or bilingual education can harm children. On the contrary, the learning and acquisition of a second language will improve children's academic performance. It is therefore of cardinal importance that strong bilingual education models are used.

There are various forms of bilingual education and it is vitally important that bilingual education is promoted in such a way that equal educational opportunities are created for minority groups as well. ${ }^{38}$

Additive bilingual education is in my view the best and most successful form of bilingual education, since learners start their school careers with mother-tongue education, after which a second language (usually English) will be added. Additive bilingual education will be advantageous to learners and it will develop successful bilingual individuals. The reason for this can be attributed to the fact that the two languages (mother tongue and secondary language) and cultures are seen as "mutually enriching".

Additive bilingual education models will flourish if schools and communities: ${ }^{40}$

- provide sufficient funds to promote bilingual education extensively; and

- make provision for sufficient teaching and learning time.

In other words, bilingual education will thrive with continued hard work and dedication.

\footnotetext{
35 Snayers and Du Plessis "Moedertaalonderrig en Tweetalige Onderwys - Perspektiewe op die Voertaal-vraagstuk in Suid-Afrikaanse Skole" 2006 Tydskrif vir Geesteswetenskappe 56. 36 Ibid.

37 See, in general, Freeman Bilingual Education and Social Change (1998) 247.

38 Snayers and Du Plessis 2006 Tydskrif vir Geesteswetenskappe 52.

39 Snayers and Du Plessis 2006 Tydskrif vir Geesteswetenskappe 52-53.

40 Ibid.
} 


\section{Types of strong bilingual education models}

There are seven types of strong bilingual education models, but for purposes of this study, only two types will be discussed. The reason for this is that these two types are the most related to the South African context. ${ }^{41}$

Maintaining model (Handhawing): Both the majority and minority language are used throughout the "minority child's" school career. It takes place through the use of compartmentalization, which aims to preserve and develop the minority language and to promote and expand the history and culture of the minority group.

Mainstream bilingual model: Two majority languages are used throughout the child's school career.

The following table explains the functioning of the aforementioned two models and also illustrates the objectives and goals that can be achieved if these models are used:

\begin{tabular}{|l|l|l|l|}
\hline \multicolumn{1}{|c|}{ Model } & \multicolumn{1}{|c|}{$\begin{array}{c}\text { Language(s) } \\
\text { used }\end{array}$} & \multicolumn{1}{c|}{$\begin{array}{c}\text { Pedagogical } \\
\text { objective/goal }\end{array}$} & \multicolumn{1}{c|}{$\begin{array}{c}\text { Linguistic } \\
\text { objective/goal }\end{array}$} \\
\hline $\begin{array}{l}\text { Maintaining } \\
\text { model }\end{array}$ & $\begin{array}{l}\text { Minority and } \\
\text { majority language }\end{array}$ & $\begin{array}{l}\text { Pluralism and } \\
\text { enrichment }\end{array}$ & Bilingualism \\
\hline $\begin{array}{l}\text { Mainstream } \\
\text { bilingual model }\end{array}$ & $\begin{array}{l}\text { Two majority } \\
\text { languages }\end{array}$ & $\begin{array}{l}\text { Enrichment and } \\
\text { pluralism }\end{array}$ & Bilingualism \\
\hline
\end{tabular}

It is apparent that these two models emphasize the maintaining and preservation of mother tongue within an education system and the pursuit of "strong bilingualism". Mother tongue is central in both these models, which provides inimitable proof of the importance of mother-tongue education. ${ }^{42}$

In conclusion, when bilingual education is implemented, the following principles should be considered: $:^{43}$

- Bilingual staff and administration

- Highly qualified bilingual teachers

- Active parent participation

- Bilingual context (the promotion of bilingualism and the prevention of monolingualism)

- Inclusive educational strategies

- Varied teaching material in respect of "language teaching"

- Fair and reliable evaluation

41 Snayers and Du Plessis 2006 Tydskrif vir Geesteswetenskappe 54-56.

42 See, in general, Snayers and Du Plessis 2006 Tydskrif vir Geesteswetenskappe 56.

43 Snayers and Du Plessis 2006 Tydskrif vir Geesteswetenskappe 58. 


\section{Mother tongue-based multilingual education (MT- based MLE)}

"Language is not everything in education, but without language, everything is nothing in education."

\section{Definition}

MT-based MLE refers to "first-language-first"' in education, that is, a child's schooling begins in his or her mother tongue and later transitions to additional languages". ${ }^{45}$ MT-based MLE is also defined as "the use of students' mother tongue and two or more additional languages as Languages of instruction (Lol) in school. In other contexts, the term is used to describe bilingual education across multiple language communities - each community using their own mother tongue plus the official school language for instruction".

\section{Why MT-based MLE?}

There is profound evidence from across Africa and several other parts of the world that MT-based MLE is the most apposite and favourable solution for "bridging language gaps and disparities" in education. ${ }^{47}$ One can also say that "multilingual education helps linguistically marginalised communities bridge to the broader society, allowing them to acquire the national language without losing their own identity".

Effective MT-based MLE programmes have three goals: ${ }^{49}$

- Language: Learners develop fluency and self-confidence when their mother tongue (L1) is used. An additional language (L2) is used for communication and learning in school.

- Academic: Grade-level academic competency is accomplished in each subject. Learners are now equipped with the necessary skills to move successfully into and through the mainstream-education system where the majority language is mostly used.

44 Prof Ekkehard Wolff (2006); see also HSRC "Without Language Everything is Nothing in Education" 2006 4(3) HSRC Review 1.

45 Kadel "Mother Tongue based Multilingual Education" http://ldcnepal.org/wp-content/uploads /2010/04/MLE-Article-Newspaper-9-December-2010.pdf, accessed 2012-05-12.

46 Malone "Mother Tongue-based Multilingual Education: Implications for Education Policy" http://resources.wycliffe.net/pdf/MT-Based\%20MLE\%20programs.pdf, accessed 2012-0512.

47 Pinnock "Mother Tongue based Multilingual Education: How Can we Move Ahead?" http://www.seameo.org/_ld2008/documents/Presentation_document/Helen_Pinnock_mle_h ow do we move ahead.pdf, accessed 2012-05-12.

48 Dr Kimmo Kosonen (2009); and see also Kadel fn 45 above.

49 Malone "Bridging Languages in Education" 2006 id21 Insights Education 6; and see also in general Webley "Mother Tongue First: Children's Right to Learn in their Own Languages" http://www.eldis.org/id21 ext/insightsed5editorial.html, accessed 2012-05-14. 
- Socio-cultural: Learners treasure their heritage, language and culture and they are geared up to contribute to the development of their own community and the nation.

Thus, MT-based MLE programmes enable learners to begin their school careers in their mother tongue (L1) and to use their mother tongue for initial literacy. When initial literacy is obtained, a second language (L2) is added firstly for listening and speaking purposes and then for reading and writing purposes. Once learners gain confidence in using the official language for everyday communication, they will also learn the vocabulary and grammatical constructions with regard to more abstract academic concepts. ${ }^{50}$

The following pyramid diagram illustrates the six phases in bridging between languages in multilingual education:

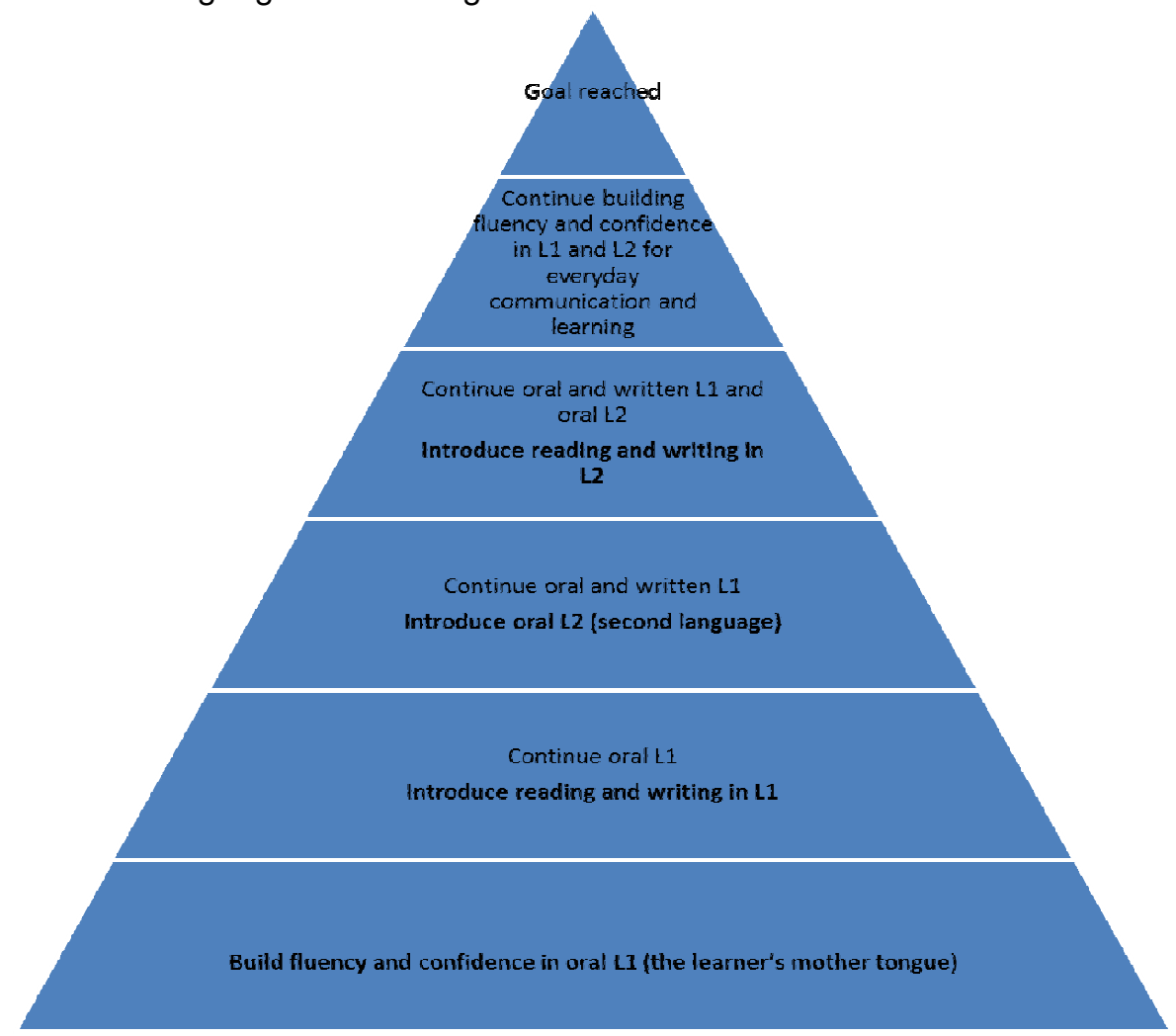

It is thus evident from the above discussion that MT-based MLE can be successful and to the benefit of all learners if it is implemented correctly. 
The radial diagram below is an example of a practice framework which supports and encourages MT-based MLE:

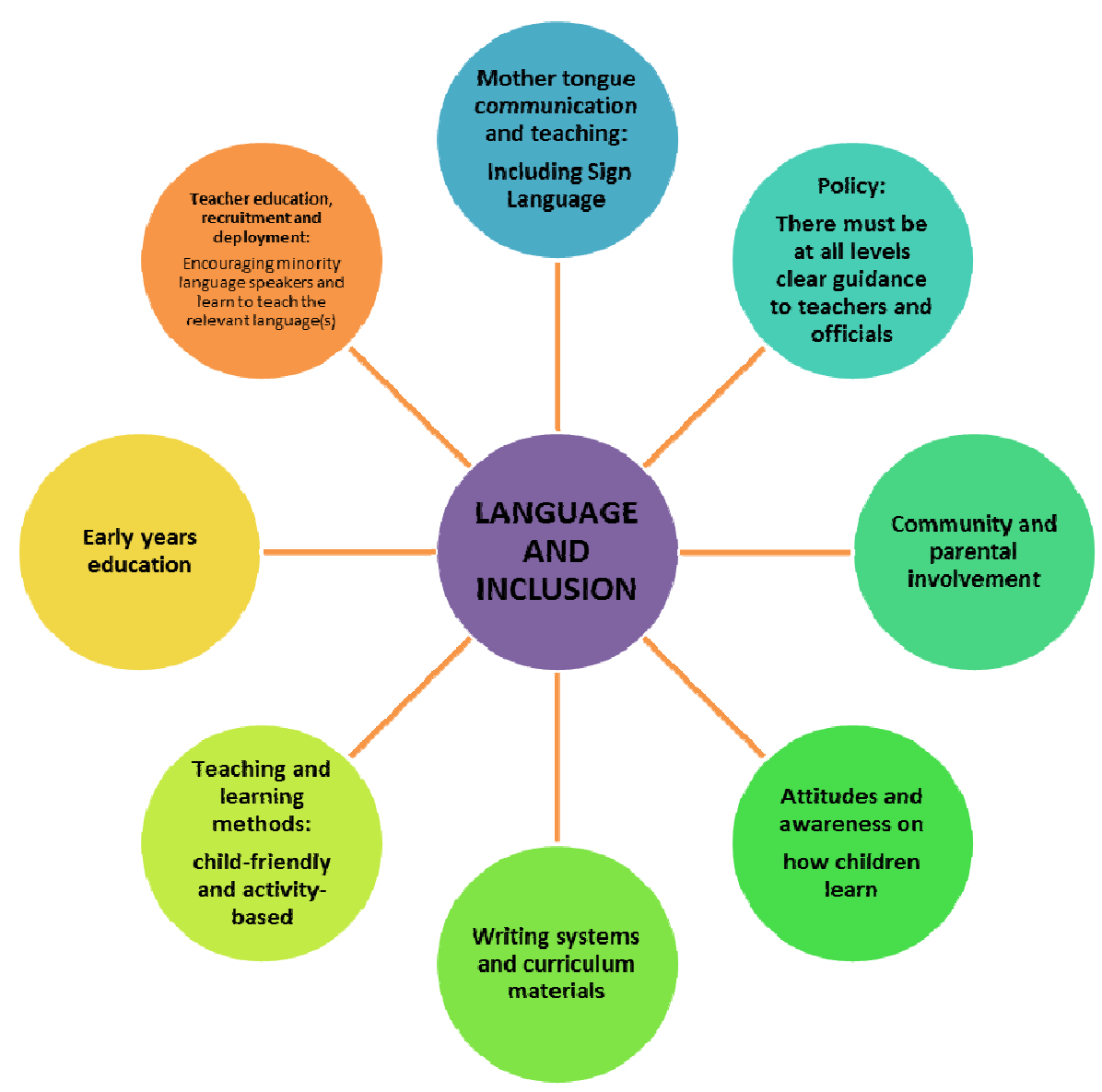

It can therefore be concluded that MT-based MLE is advantageous in several respects: ${ }^{53}$

- Status is given to indigenous languages.

- Children are enabled to have links with their cultural backgrounds and to develop close relationships with their families and wider communities.

- Employment opportunities are increased.

- Access to the curriculum and to learning in school is made possible.

- Communication between different linguistic and cultural groups is improved.

52 Pinnock, see fn 47 above.

53 Kadel, see fn 45 above. 
- Children are provided with the ability to share in a variety of intercultural experiences such as literature, entertainment, religion and several other interests.

\section{Conclusion}

Mother-tongue education is without a doubt the most important component with regard to the educational development of South African learners and the subsequent development of South African communities on social, cultural, political, religious and economic level. The suppression of mother tongue education results in reduced public access to basic rights, benefits and remedies, increased poverty and the uneven distribution of scarce resources. The denial of mother-tongue education also results in increased prejudice, discrimination and exploitation. ${ }^{54}$

It is therefore patently obvious that mother-tongue education is invaluable and to the advantage of all children. There is also a profusion of evidence in favour of mother-tongue education: ${ }^{55}$

"[A] mother tongue is a person's natural means of self expression and represents a learner's indigenous knowledge about his community's values, history and experience that the education system should build on to when developing and education him/her.

... It is universally accepted that mother tongue education is good for education. It is also universally accepted that education is indispensable to development. Mother tongue education is therefore indispensable to development."

A child, who is taught in a language other than his or her mother tongue, is confronted with many challenges and difficulties. When a child comes to the realization that he or she will be receiving education in a foreign language, a sense of fear and insecurity may be developed: ${ }^{.6}$

"Anyone who has to struggle with the force of a new language when they enter into a new learning atmosphere would understand the confusion that is experienced ... you want to understand what is going on, but you cannot because your mind is blank. You have no words in the new language to offer expression. Soon nothing the child knows or wants to know or say matters because of this language barrier."

The "narrow approach" that mother-tongue education can only be promoted successfully in monolingual (single language) schools, is a misperception of the true state of affairs. In fact, mother-tongue education can be promoted successfully through the implementation of certain education models. Strong bilingual education is one of the best education models to use in the South African context, because mother tongue and mother-tongue education retain a prominent role in the upbringing and education of children. The bilingual education models which can be implemented with great success in South Africa, is the Maintaining- and

54 Webb 2006 Tydskrif vir Geesteswetenskappe 46.

55 See in general http://www.wimsa.org, last visited 2011-10-30.

56 Ibid. 
Mainstream bilingual models. These models will benefit all language groups since they promote pluralism, enrichment and bilingualism.

MT-based MLE-education models can also be implemented with great success, since a child's education will start with his or her mother tongue and additional languages will only be added at a later stage. This model will definitely be favourable in the South African context since South Africa is a country with diverse cultures and languages and this model might be the solution for the bridging of language gaps and disparities.

In my view, bilingual education models and MT-based MLE-education models will be advantageous to all language groups and should therefore be promoted and encouraged. However, one should remember that an education model which benefits only one language group should be approached with great care because such a model is ineffective and causes unnecessary language disputes.

The views and opinions that speakers of minority-language groups should guard against language disputes, is only realizable and doable in an ideal world with no ideological undercurrents and where absolute equality reigns. It can therefore be argued that, if a language is only spoken and not promoted and/or further developed, all the progress towards recognition and standardization are disregarded. ${ }^{57}$

Mother tongue education is thus the "cultural capital" of access, participation and inclusion and South Africa as a nation has the responsibility to combat language challenges and to promote and encourage multilingualism, equal language opportunities and educational justice. ${ }^{58}$

It can therefore be unequivocally declared that mother-tongue education is in the best interests of every child, but in my view, we must not be blinded by "monolingual education" only. Bilingual education and mother-tongue based multilingual education can be successfully implemented in a country like South Africa where a diversity of language(s) prevails.

In conclusion, when mother-tongue education comes under the spotlight, the following must always be remembered: ${ }^{59}$

"To achieve success in education, we need to achieve success in our approaches to and celebration of language."

\section{INTERNATIONAL INSTRUMENTS AND NATIONAL LEGISLATION}

The cardinal importance of language and mother-tongue education is also emphasized in various international instruments and national legislation.

\footnotetext{
57 Van Niekerk and De Wet "Supplementuitgawe: Tydskrif vir Geesteswetenskappe Moedertaalonderrig" 2006 Tydskrif vir Geesteswetenskappe 4.

58 Le Mottee, see fn 8 above.

59 Ibid.
} 


\section{International instruments}

There are several international instruments which deal with language and mother-tongue education. For purposes of this study, seven international instruments will be discussed.

\section{The Declaration of the Rights of Persons Belonging to National or Ethnic, Religious and Linguistic Minorities}

Article 4(2) stipulates that states shall take measures to create favourable conditions to enable persons belonging to minorities to express their characteristics and to develop their culture, language, religion, traditions and customs, except where specific practices are in violation of national law and contrary to international standards.

States are required in article 4(3) to take appropriate measures so that, wherever possible, persons belonging to minorities may have adequate opportunities to learn their mother tongue or to have instruction in their mother tongue.

Article 4(4) also stipulates that states should, where appropriate, take measures in the field of education, in order to encourage knowledge of the history, traditions, language and culture of the minorities existing within their territory.

\section{The International Labour Convention (No 169) Concerning Indigenous and Tribal Peoples in Independent Countries}

Article 28(1) stipulates that children belonging to the peoples concerned shall, wherever practicable, be taught to read and write in their own indigenous language or in the language most commonly used by the group to which they belong. When this is not practicable, the competent authorities shall undertake consultations with these peoples with a view to the adoption of measures to achieve this objective.

Article 28(2) states that adequate measures shall be taken to ensure that these peoples have the opportunity to attain fluency in the national language or in one of the official languages of the country.

Article 28(3) also states that measures shall be taken to preserve and promote the development and practice of the indigenous languages of the peoples concerned.

\section{The UN Declaration on the Rights of Indigenous Peoples}

Article 14(1) specifies that indigenous peoples have the right to establish and control their educational systems and institutions providing education in 
their own languages, in a manner appropriate to their cultural methods of teaching and learning.

Article 14(2) states that indigenous individuals, particularly children, have the right to all levels and forms of education of the state without discrimination.

Article 14(3) stipulates that states shall, in conjunction with indigenous peoples, take effective measures, in order for indigenous individuals, particularly children, including those living outside their communities, to have access, when possible, to an education in their own culture and provided in their own language.

\section{The UN Universal Declaration on Human Rights}

Article 2 stipulates that everyone is entitled to all the rights and freedoms set forth in this Declaration, without distinction of any kind such as race, colour, sex, language, religion, political or other opinion, national or social origin, property, birth or other status.

Article 26 stipulates that everyone has the right to education without discrimination. As seen from above, article 2 prohibits discrimination on the grounds of language.

\section{The UN Convention and Recommendation against Discrimination in Education}

Article 5(1)(c) stipulates that states parties to this convention agree that it is essential to recognize the right of members of national minorities to carry on their own education activities, including the maintenance of schools and, depending on the educational policy of each state, the use or the teaching of their own language.

\section{The African Charter on the Rights and Welfare of the Child (ACRWC)}

Article 11 states that every child shall have the right to an education. Article 3 states that every child shall be entitled to the enjoyment of the rights and freedoms recognized and guaranteed in this Charter irrespective of the child's or his or her parents' or legal guardians' language.

One can thus say that every child has the right to an education in his or her mother tongue, where reasonably practicable, since article 3 prohibits discrimination on the grounds of language. It would be in the best interests of the child to receive education in his or her mother tongue. In short, discrimination based on language is prohibited, which in turn is equivalent to the right to mother-tongue education. However, to provide mother-tongue education is not always reasonably practicable. Two questions need to be asked: What type of right is the right to mother-tongue education; and what is meant by reasonably practicable? 
The right to an education in one's mother tongue or language of choice is not an unqualified right, but a positive right. The extent of this right is "specifically demarcated by the requirement of reasonable practicability". 60 This means that circumstances must warrant the right to receive education in a language of choice and that the necessary resources and administrative capacity must be available in order to give effect to this right. ${ }^{61}$ However, with regard to reasonably practicable, the following can be emphasized: "[t]he standard of reasonableness means that where mother tongue education is not provided there must be an objective justification for the denial of the right. International practice suggests that denial of the right can be justified by reference to a sliding scale". ${ }^{2}$ The formula which is used to determine whether there is an objective justification for the denial of the right to receive education in a language of choice, is as follows: The greater the number of speakers of a particular language in a specific area, the greater the obligation of government to provide for instruction (education) in that language. However, the higher the level of education, the less pressing and urgent the obligation becomes to provide mother-tongue education.

It must be borne in mind that the provision of mother-tongue education at primary school level appears to be unavoidable since many children do not have the necessary understanding of any other language than their own mother tongue. However, the strongest case for the provision of mothertongue education lies on the internationally accepted right of access to good quality, basic education. ${ }^{64}$

\section{The UN Convention on the Rights of the Child (UNCRC)}

The UNCRC can, with regard to language and education, be divided into two categories of rights, namely child rights and parental rights:

\section{Child rights}

Article 30 stipulates that in those states in which ethnic, religious or linguistic minorities or persons of indigenous origin exist, a child belonging to such a minority or who is indigenous, shall not be denied the right, in community with other members of his or her group, to enjoy his or her own culture, to profess and practise his or her own religion, or to use his or her own language.

UNCRC General Comment 7 states that "young children are holders of all rights enshrined in the Convention. Early childhood (from birth to 8 years) is a critical period for realization of these rights. Programmes and policies are

60 Prinsloo "The Right to Mother Tongue Education: A Multidisciplinary, Normative Perspective" 2007 Southern African Linguistics and Applied Language Studies 34-35.

1 lbid.

62 De Waal, Currie and Erasmus The Bill of Rights Handbook (2001) 484.

63 Prinsloo 2007 South African Linguistics and Applied Language Studies 34-35.

64 Ibid. 
required to realize rights in early childhood. These policies and programmes must recognize and incorporate diversities in culture, language, and child rearing". 65

\section{Parental rights}

Article 29(1)(c) stipulates that states parties agree that the education of the child shall be directed to the development of respect for the child's parents, his or her own cultural identity, language and values, for the national values of the country in which the child is living, the country from which he or she may originate, and for civilizations different from his or her own.

Article 5 also stipulates that states parties shall respect the responsibilities, rights and duties of parents or, where applicable, the members of the extended family or community as provided for by local custom, legal guardians or other persons legally responsible for the child, to provide, in a manner consistent with the evolving capacities of the child, appropriate direction and guidance in the exercise by the child of the rights recognized in the present Convention.

However, the rights with regard to language and education in general can be divided into three categories and the following figure illustrates these three classes: ${ }^{.6}$

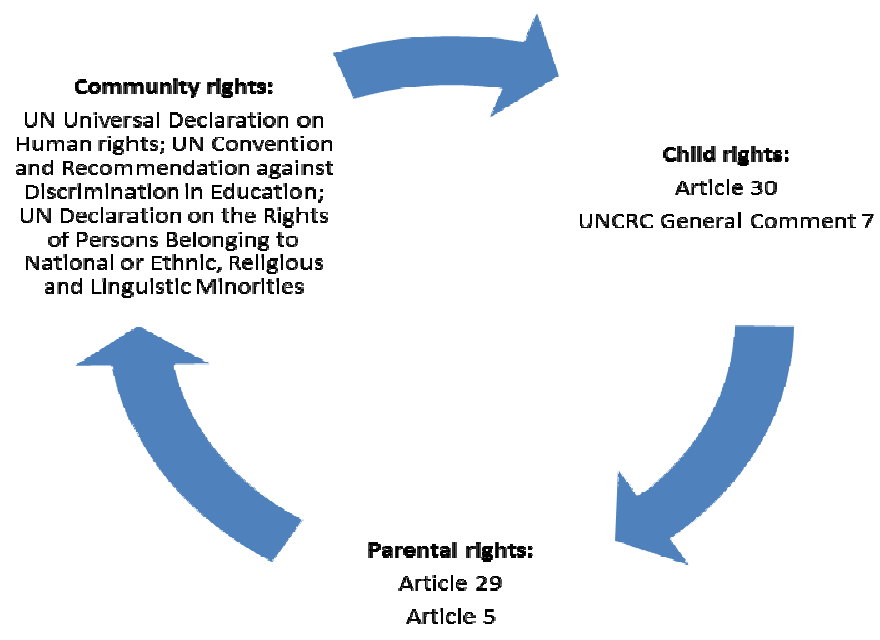

The position with regard to community rights has already been discussed in paragraphs 711,714 and 715 , below.

\footnotetext{
Ibid.

66 See, in general Ball "Promoting Children's Rights to Use their Mother Tongue in Early Education" http://www.seameo.org/.../doc/presentations/day1/JessicaBall-sn-ecd.pdf, accessed 2011-10-18.
} 


\section{National legislation}

South African national legislation also provides for "language rights". Several sections of the South African Constitution, the National Education Policy Act and the South African Schools Act have already been discussed under paragraph 3 2. Section 29(2) of the South African Constitution, which specifically deals with education in one's preferred language, will now be discussed in full.

\section{Section 29(2)}

Section 29(2) of the Constitution stipulates that everyone has the right to receive education in the official language or languages of their choice in public educational institutions where that education is reasonably practicable. In order to ensure the effective access to, and implementation of, this right, the state must consider all reasonable educational alternatives, including single medium institutions, taking into account equity, practicability and the need to redress the results of past racially discriminatory laws and practices.

In simple terms, section 29(2) can be explained as follows:

Section 29(2) states that everyone should enjoy the right to receive education in his or her preferred language in public educational institutions where that education is "reasonably practicable". ${ }^{67}$ The right to receive education in the official language of one's choice in public educational institutions is therefore of a qualified nature. This means that the importance of mother-tongue education is taken into account, but that the provision of mother-tongue education should also be reasonably practicable. ${ }^{68}$ "Reasonably practicable" means that every learner (in case of a minor, his or her parents or legal guardian(s)) must choose the preferred language of teaching on admission to a particular school. If the preferred language chosen is unavailable, the learner is allowed to request his or her preferred language. The question now is what is exactly meant by "reasonably practicable"? "Reasonably practicable" means something that is reasonable to the degree of being practical - something that can be done, implemented or achieved without difficulty. Accordingly "reasonably practicable" would be to provide education in a particular language if no fewer than 40 learners in grades one to six or 35 learners in grades seven to twelve request a particular language at a particular school. ${ }^{69}$

When a particular language is requested and the number of learners is below the aforementioned numbers, the Head of the Department of Education is required to come forward with possible solutions. The Head of the Department of Education is obliged to consider the advice and recommendations of the school governing body, the principal and the school

67 Anon "Language rights and schools" http://www.erp.org.za/htm/issuepg_lang.htm, accessed 2012-05-12.

68 Robinson "Children's Rights in the South African Constitution" 2003 6(1) PER 33-35.

69 Anon, see fn 67 above. 
in general. Factors such as "the need to achieve equity and the need to redress racially discriminatory practices" should be taken into consideration. ${ }^{70}$ Other relevant factors such as costs, availability of facilities and educators, as well as distances to comparable schools where the "preferred mother tongue education" is provided, should also be considered. $^{71}$

If a learner or school governing body is not satisfied with the Head of Department's decision, they may appeal to the MEC for Education in the relevant province within a time period of 60 days. If they are still not satisfied, they may approach the Pan South African Language Board or the Arbitration Foundation of South Africa. ${ }^{72}$

Section 29(2) can thus be described as an empowerment clause, "because its actual intention is to extend educational opportunities to as many South Africans as possible". ${ }^{73}$

There are some implications with regard to section 29(2) that need to be emphasized:

- Section 29(2) states that ... in order to ensure the effective access to, and implementation of, this right, the state must consider all reasonable educational alternatives, including single-medium institutions ... This means that the state is obliged to give this right the attention it deserves and the state also has to prove that the right to receive education in one's preferred language is executed effectively.

- The right to receive education in one's preferred language is subject to the practicability test and not to the factors "equality, practicability and the need to redress the results of past racially discriminatory laws and practices" contained in section 29. These factors deal with the best alternative to provide the right effectively and is applicable only to the "determination of the best alternative to give effect to the right ..."

- Section 29(2) specifically refers to single-medium institutions. This means that dual- and parallel-medium education could also be included as alternatives, but within a range of possibilities.

- Any views and opinions that single-medium institutions impede the redress of past discrimination are unfounded and groundless, because the highest standard of education can be made available to all South Africans through mother tongue.

- Dual- and parallel-medium institutions are in some instances the best alternative to comply with the right to receive education in one's preferred language. However, it has the shortcoming that the reduced numbers of a particular language group can put enormous pressure on that language which may lead to single-medium instruction. Consequently, the right of 
those learners who prefer education in a particular language is then at risk.

To conclude, the Constitution explicitly provides for the right to receive education in one's preferred language. However, the following should be remembered: ${ }^{75}$

"Single-medium educational institutions are not a guaranteed right, but must be considered whenever the best alternative to provide the right to education in one's preferred language must be chosen. Even when a single-medium institution proves not to be the best alternative, the duty remains on the state to provide education in one's preferred language effectively."

\section{MOTHER-TONGUE EDUCATION - A SUBJECT OF LITIGATION}

Section 29(2) has provoked strong reaction and led to several lawsuits.

\section{Laerskool Middelburg v Departementshoof, Mpumalanga Departement van Onderwys ${ }^{76}$}

Laerskool Middelburg is an Afrikaans-medium public school with Afrikaans as the exclusive medium of instruction. On 28 November 2011, the school was instructed to enrol 20 learners who wished to attend the school from January 2002 and to be taught in English. In other words, Laerskool Middelburg had to change from a single-medium Afrikaans school to a parallel-medium school. The school refused to comply with this instruction and informed the parents of these learners in writing that their applications for admission were not successful since Laerskool Middelburg was a singlemedium Afrikaans school. On 14 January 2002, the principal's power to admit learners was revoked by the department. On 15 January 2002, a certain Mr Mampana (an official of the department) arrived at the school and enrolled eight learners who preferred English as medium of instruction.

The court argued erroneously that section 29(2) made provision for a right to single-medium schools, but in this case, the court held that the department had violated the "capacity regulation(s)". The regulation(s) stated indisputably that "the schools which offered the tuition in the desired language had to be at full capacity before the status of a single medium school could be changed". ${ }^{78}$

However, from the report of the curator, it appears that the learners (a total of 24) could have been accommodated with ease at any of the other schools in the district. These learners could have been accommodated without difficulties in either Kanonkop Primary School or Dennesig Primary School, which were both parallel-medium schools. There was also Middelburg Primary School, which was a single-medium English school with

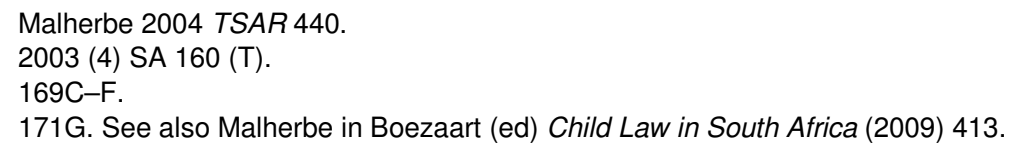


English as medium of instruction. If these learners were enrolled in any of the aforementioned schools, there would have been no change to their language policies. However, the enrolment of these learners in Laerskool Middelburg would change its language policy and school setting(s) ${ }^{79}$

It is thus clear from the above that the department had infringed the school's and the governing body's powers. As a result of the department's "excess of powers", Laerskool Middelburg approached the court to set aside the department's and its officials' decision to declare Laerskool Middelburg a parallel medium school. ${ }^{80}$

Unfortunately, there was a long delay of almost nine months before the school brought its application to the court. The learners had already been attending the school for these eight months and it would be in the best interests of every learner to continue with schooling in Laerskool Middelburg. ${ }^{81}$ If the application was brought before the court at an earlier stage, the decision would probably have been different: the department's infringement of the school's and governing body's powers would have been set aside. ${ }^{82}$

The school's application to set aside the decision of the department to declare Laerskool Middelburg a parallel-medium school was rejected. ${ }^{83}$ The judgment was anchored in section 28(2) of the Constitution, which stipulated that "a child's best interests are of paramount importance in every matter concerning the child". ${ }^{84}$ If the learners were turned away, their best interests would be affected. Their "right to education" would be disrupted because they would have to enrol and register at a new school. Moreover, possible close relations could have been formed with classmates by then - an indication that these learners had already to a large extent adapted to the school and school environment.

The Western Cape Education Department exercised the same pressure on the Mikro Primary School. The department instructed the school to change from an Afrikaans single-medium school to a parallel-medium school. The case is discussed below.

\section{Minister of Education, Western Cape v Governing Body, Mikro Primary Schoo ${ }^{55}$}

Mikro Primary school was founded in 1972 and has been a single-medium Afrikaans school since 1973. On 2 December 2004, the principal was instructed to enrol a group of grade-1 learners for the upcoming year (January 2005). The principal was also instructed to offer this group of

\footnotetext{
172D-E. See also Malan "Die Grondwet, Onderwysowerhede en die Pad Vorentoe vir Afrikaanse Skole" 2010 Tydskrif vir Geesteswetenskappe 268.

80 168I-J.

81 178D-G. See also Malan 2010 Tydskrif vir Geesteswetenskappe 269.

82 Ibid.

$83179 \mathrm{C}$.

$178 \mathrm{C}-\mathrm{D}$

2006 (1) SA 1 (SCA).
} 
learners their education in English. The school was informed that if the principal (and school) refused to comply with this instruction, disciplinary action would be taken against the principal. On 19 January 2005, two senior members of the Education Department arrived at the Mikro Primary School and enrolled 21 grade-1 learners who wished to be instructed in English. ${ }^{86}$

There was also (as in the Middelburg case), another parallel-medium school, De Kuilen Primary School, that taught in both Afrikaans and English. The 21 learners could have been easily accommodated in this school. ${ }^{87}$

Mikro Primary School brought a court application requesting the court to review and set aside the Department's decision regarding the admission of grade-1 learners and their wish to receive their education in English. ${ }^{88}$

The court a quo ruled in favour of the Mikro Primary School and found that the Department had acted unlawfully by compelling the school to admit learners contrary to the school's language policy. ${ }^{89}$ The court also ordered that the department and its officials were not allowed to interfere with the school's professional activities and management. There was an obligation on the department and its officials to ensure that that group of learners were admitted in other schools. ${ }^{90}$

The department appealed against the court a quo's decision. The Supreme Court of Appeal also ruled in favour of Mikro Primary School, and the appeal was dismissed with costs. ${ }^{9}$

It is thus evident that the department exceeded its powers in an incorrect and unlawful manner. Visser's opinion on the Mikro case is without doubt correct. He said the following: ${ }^{92}$

"The judgment in casu is undoubtedly correct on the facts. The ill-advised interference from and high-handed action of the Cape education authorities, were clearly irregular and illegal."

\section{Seodin Primary School v MEC of Education, Northern Cape ${ }^{93}$}

The Seodin-case is another example that illustrates the huge amount of pressure that is placed on single-medium schools to convert to parallelmedium schools.

\footnotetext{
8I-27B, see also Lubbe "Afrikaans-moedertaalonderrig onder Beleg" 2006 Stellenbosch Ibid.

88 9A-D. See also Lubbe 2006 Stellenbosch Papers in Linguistics PLUS 59.

89 9C. See also Lubbe 2006 Stellenbosch Papers in Linguistics PLUS 59.

90 See, in general, Malan 2010 Tydskrif vir Geesteswetenskappe 269-270.

91 26l. See also Lubbe 2006 Stellenbosch Papers in Linguistics PLUS 59.

92 Visser "Education Law - Language Policy at Single-medium Public School - Section 29(2) of the Constitution - Irregular Interference by Provincial Education Department: Western Cape Minister of Education v Governing Body of Mikro Primary School Case No 140/2005 (SCA)" 2006 THRHR 339.

93 [2006] 1 All SA 154 (NC).
} 
On 31 August 2004, six schools, namely Seodin Primary School, Kalahari High School, Kuruman Primary School, Wrenchville Primary School, Wrenchville Secondary School and the Northern Cape Agricultural High School, were instructed to convert to dual-medium Afrikaans-and-English schools. $^{94}$

On 1 September 2004, the schools were informed by the head of the Education Department as follows: ${ }^{95}$

"I propose to admit the learners as follows:

(a) The learners presently in Grade 7 at Kuruman Primary School will be admitted to Grade 8 at Kalahari High School.

(b) The Grade 7 learners at Wrenchville Primary School will proceed to Wrenchville Secondary School.

(c) 200 Learners will be transferred from Wrenchville Primary School to Seodin Primary School.

(d) 150 Learners will be transferred from Wrenchville Primary School to Kuruman Primary School.

(e) The Grade 10 to 12 at Bankhara-Bodulong will be transferred to Kalahari High School and Bankhara-Bodulong will no longer offer grades in the FET (Further Education and Training) phase of the curriculum.

(f) All new Grade 1 applicants will be distributed equitably among the primary schools.

You are called upon to comment on these proposals by 8 September 2004. The public will be informed immediately of the MEC's decision and the procedure outlined above. They will also be encouraged to start applying now

to ensure that no time is lost in finalising the admissions for next year.

I am looking forward to receiving your advices."

It is clear from the above that the schools had no other choice than to approach the court. Three of the schools, namely, Seodin Primary School, Kalahari High School and Northern Cape Agricultural School brought an application to the court requesting the court to review and/or set aside the MEC's decision to convert to and function as dual-medium Afrikaans-andEnglish schools as well as the MEC's decision taken on 1 September 2004 (see above). ${ }^{96}$

Unfortunately, the three schools' application was rejected, mainly on the grounds of "non-compliance with section 6(2) of the Schools Act". Kgomo JP stated that none of the three schools had an approved language policy as determined in section 6(2) of the Schools Act. ${ }^{97}$

\section{Head of Mpumalanga Department of Education $v$ Hoërskool Ermelo ${ }^{98}$}

Hoërskool Ermelo is a leading Afrikaans school in Mpumalanga. At the end of 2001, the head of the Mpumalanga Education Department disbanded the

\footnotetext{
94156 par 3; and see also Lubbe 2006 Stellenbosch Papers in Linguistics PLUS 60-61.

95164 par 11.

$96 \quad 156$ par 3.

97188 par 62; and see also Lubbe 2006 Stellenbosch Papers in Linguistics PLUS 61.

982010 (3) BCLR 177 (CC).
} 
governing body of the school. The principal of the school was also dismissed, and the school was instructed to convert to a parallel-medium school. The disbanded governing body had no choice other than to approach the court. The ensuing litigation brought some relief: the principal was reinstated in his post and the school remained a single-medium Afrikaans school. ${ }^{99}$

A day before the schools reopened in 2007, the head of the Mpumalanga Education Department instructed Hoërskool Ermelo to use English also as a medium of instruction, because there were some learners who preferred to be taught in English. ${ }^{100}$ The head of the Mpumalanga Education Department also appointed an interim committee, who had the task to amend the school's language policy. It was clear that the language policy had to be changed in such a way that 113 learners (who preferred English as a medium of instruction) who allegedly could not be accommodated elsewhere be accommodated in Hoërskool Ermelo. The interim committee met on the same day and decided that the language policy of the school would from then on be parallel medium. ${ }^{101}$

What is extremely disturbing is that this decision was taken without prior consultation of any kind. The interim committee's decision was solely based on information that was given by representatives of the Mpumalanga Education Department. ${ }^{102}$

Later that day, the head of the Mpumalanga Education Department addressed a letter to the school governing body in which they were told that the function of the governing body to determine the school's language policy was revoked with immediate effect. ${ }^{103}$

The governing body approached the High Court for an interdict against the Mpumalanga Education Department, and their application was successful. However, a few days later, the "case" was reviewed and the school's application was dismissed. ${ }^{104}$

Hoërskool Ermelo appealed to the Supreme Court of Appeal, and the decision of the court lead to a major turnabout in favour of Hoërskool Ermelo. The court ordered as follows:

99 See, in general Schoombee v MEC for Education, Mpumalanga 2002 (4) SA 877 (T). See also Malan 2010 Tydskrif vir Geesteswetenskappe 270.

100 Hoërskool Ermelo v Head, Department of Education, Mpumalanga 2009 (3) SA 422 (SCA) par 2 G-H. See also Malan 2010 Tydskrif vir Geesteswetenskappe 270.

101 Hoërskool Ermelo v Head, Department of Education, Mpumalanga 2009 (3) SA 422 (SCA) par $11 \mathrm{~F}-\mathrm{I}$. See also Malan 2010 Tydskrif vir Geesteswetenskappe 270-271.

102 Hoërskool Ermelo v Head, Department of Education, Mpumalanga 2009 (3) SA 422 (SCA) par 12 A-B. See also Malan 2010 Tydskrif vir Geesteswetenskappe 271.

103 Hoërskool Ermelo v Head, Department of Education, Mpumalanga 2009 (3) SA 422 (SCA) par H-I. See also Malan 2010 Tydskrif vir Geesteswetenskappe 271.

104 Hoërskool Ermelo v Head, Department of Education, Mpumalanga 2009 (3) SA 422 (SCA) par 13 C-D. See also Malan 2010 Tydskrif vir Geesteswetenskappe 271.

105 Hoërskool Ermelo v Head, Department of Education, Mpumalanga 2009 (3) SA 422 (SCA) par $34 \mathrm{C}-\mathrm{F}$. 
"1. The appeal is upheld.

2. The order of the court a quo is set aside and replaced by the following:

(a) The first respondent's decision to withdraw the function of the governing body of Hoërskool Ermelo to determine the language policy of the school is set aside.

(b) The first respondent's decision to appoint an interim committee to perform the function of the governing body to determine the language policy of Hoërskool Ermelo is set aside.

(c) The decision of the interim committee to amend the language policy of Hoërskool Ermelo from Afrikaans medium to parallel medium is set aside.

(d) Learners that have enrolled at Hoërskool Ermelo since 25 January 2007 in terms of a parallel medium language policy shall be entitled to continue to be taught and write examinations in English until the completion of their school careers."

The Constitutional Court held that the department was permitted in terms of section 22 of the Schools Act to withdraw the governing body's powers, which allowed the governing body in terms of section 6(2) of the Schools Act to determine the school's language policy. However, it could only be done on reasonable grounds. ${ }^{106}$ In other words: the governing body of a school did not have the exclusive power to determine the language policy of a school. ${ }^{107}$

The court also held that in terms of section 6(1) of the Schools Act, the Minister might determine norms and standards for a language policy. Thus, the power to determine the language policy of a school was shared between the Minister and the governing body of a school. ${ }^{108}$

The court addressed another problem, namely the lack of space in schools to educate learners, especially those learners who preferred English as medium of instruction. This state of affairs hampered the right in terms of section 29(2) of the Constitution to receive education in the official language or languages of one's choice. The court was of the opinion that this problem could be partly solved by Hoërskool Ermelo, because the school had enough room to accommodate more learners, while other schools in the same district were jam-packed. ${ }^{109}$

In view of this, the court ordered the governing body of Hoërskool Ermelo to review its language policy and report back to the court. ${ }^{110}$ It was also ordered that the department report back to the court "setting out the steps it has taken to satisfy the likely demand for an English or parallel-medium high

106 Head of Mpumalanga Department of Education v Hoërskool Ermelo 2010 (3) BCLR 177 (CC) par 68-93. See also Malan 2010 Tydskrif vir Geesteswetenskappe 273.

107 Head of Mpumalanga Department of Education v Hoërskool Ermelo 2010 (3) BCLR 177 (CC) par 77 and 93. See also Malan 2010 Tydskrif vir Geesteswetenskappe 273.

108 Head of Mpumalanga Department of Education v Hoërskool Ermelo 2010 (3) BCLR 177 (CC) par 60

109 Head of Mpumalanga Department of Education v Hoërskool Ermelo 2010 (3) BCLR 177 (CC) par 9 and 12. See also Malan 2010 Tydskrif vir Geesteswetenskappe 276.

110 Head of Mpumalanga Department of Education v Hoërskool Ermelo 2010 (3) BCLR 177 (CC) par 102 and 106, item 4. 
school in the Ermelo district, as well as on the situation at other high schools in the area".

Finally, one should remember that the right to receive education in one's preferred language is guaranteed in section 29(2) of the Constitution. Nonetheless, single-medium institutions are not guaranteed in the Constitution, but these single-medium institutions must be taken into consideration "whenever the most appropriate alternative to provide the right to education in one's preferred language must be selected".

\section{Middelburg, Mikro, Seodin and Ermelo: A comparison}

The aforementioned cases have a lot in common, but there are some differences too. The following table sets out the similarities and differences:

\begin{tabular}{|c|c|c|c|}
\hline Middelburg & Mikro & Seodin & Ermelo \\
\hline $\begin{array}{l}\text { Single-medium } \\
\text { Afrikaans school }\end{array}$ & $\begin{array}{l}\text { Single-medium } \\
\text { Afrikaans } \\
\text { school }\end{array}$ & $\begin{array}{l}\text { Single- } \\
\text { medium } \\
\text { Afrikaans } \\
\text { school }\end{array}$ & $\begin{array}{l}\text { Single-medium Afrikaans } \\
\text { school }\end{array}$ \\
\hline $\begin{array}{l}\text { School was } \\
\text { instructed to } \\
\text { enrol } 20 \text { learners } \\
\text { who wished to } \\
\text { receive } \\
\text { education in } \\
\text { English. } \\
\\
\text { (School will have } \\
\text { to convert to a } \\
\text { parallel-medium } \\
\text { school) }\end{array}$ & $\begin{array}{l}\text { School was } \\
\text { instructed to } \\
\text { enrol a group } \\
\text { of grade-1 } \\
\text { learners who } \\
\text { preferred } \\
\text { English as } \\
\text { medium of } \\
\text { instruction. } \\
\text { (School will } \\
\text { have to convert } \\
\text { to a parallel- } \\
\text { medium } \\
\text { school) }\end{array}$ & $\begin{array}{l}\text { Several } \\
\text { schools were } \\
\text { instructed to } \\
\text { convert to } \\
\text { dual-medium } \\
\text { Afrikaans- } \\
\text { and-English } \\
\text { schools. }\end{array}$ & $\begin{array}{l}\text { School was instructed to } \\
\text { also use English as a } \\
\text { medium of instruction, } \\
\text { because there were some } \\
\text { learners who preferred to } \\
\text { be taught in English. } \\
\text { Interim committee was } \\
\text { appointed to change the } \\
\text { language policy of the } \\
\text { school. }\end{array}$ \\
\hline $\begin{array}{l}\text { Learners could } \\
\text { have been easily } \\
\text { accommodated } \\
\text { in other parallel- } \\
\text { medium schools: } \\
\text { Kanonkop } \\
\text { Primary School } \\
\text { or Dennesig } \\
\text { Primary School } \\
\text { OR in the single- } \\
\text { medium English } \\
\text { school: } \\
\text { Middelburg } \\
\text { Primary School. }\end{array}$ & $\begin{array}{l}\text { Learners could } \\
\text { have been } \\
\text { easily } \\
\text { accommodated } \\
\text { in another } \\
\text { parallel- } \\
\text { medium } \\
\text { school: De } \\
\text { Kuilen Primary } \\
\text { School. }\end{array}$ & & $\begin{array}{l}\text { Apparently, these learners } \\
\text { could not be } \\
\text { accommodated elsewhere } \\
\text { - other schools were jam- } \\
\text { packed. }\end{array}$ \\
\hline
\end{tabular}

111 Malherbe in Boezaart Child Law in South Africa (2009) 415. See also Head of Mpumalanga Department of Education v Hoërskool Ermelo 2010 (3) BCLR 177 (CC) par 104 and 106, item 5.

112 Malherbe in Boezaart Child Law in South Africa (2009) 415. 


\begin{tabular}{|c|c|c|c|}
\hline Middelburg & Mikro & Seodin & Ermelo \\
\hline $\begin{array}{l}\text { School } \\
\text { approached the } \\
\text { court to set } \\
\text { aside the } \\
\text { department's } \\
\text { decision to } \\
\text { declare the } \\
\text { school a parallel- } \\
\text { medium school. }\end{array}$ & $\begin{array}{l}\text { School has } \\
\text { brought an } \\
\text { application } \\
\text { requesting the } \\
\text { court to review } \\
\text { and set aside } \\
\text { the } \\
\text { department's } \\
\text { decision } \\
\text { regarding the } \\
\text { admission of } \\
\text { the grade-1 } \\
\text { learners and } \\
\text { their wish to } \\
\text { receive } \\
\text { education in } \\
\text { English. }\end{array}$ & $\begin{array}{l}\text { Three schools } \\
\text { brought an } \\
\text { application to } \\
\text { the court } \\
\text { requesting the } \\
\text { court to } \\
\text { review and/or } \\
\text { set aside the } \\
\text { MEC's } \\
\text { decision to } \\
\text { convert to and } \\
\text { function as } \\
\text { dual-medium } \\
\text { Afrikaans- } \\
\text { and-English } \\
\text { schools. }\end{array}$ & $\begin{array}{l}\text { The governing body of the } \\
\text { school approached the } \\
\text { court for an interdict } \\
\text { against the department. }\end{array}$ \\
\hline $\begin{array}{l}\text { Schools } \\
\text { application to set } \\
\text { aside the } \\
\text { department's } \\
\text { decision was } \\
\text { rejected. }\end{array}$ & $\begin{array}{l}\text { Court a quo } \\
\text { ruled in favour } \\
\text { of the school: } \\
\text { department } \\
\text { acted } \\
\text { unlawfully. } \\
\text { scA also ruled } \\
\text { in favour of the } \\
\text { school. The } \\
\text { department's } \\
\text { appeal was } \\
\text { dismissed with } \\
\text { costs. }\end{array}$ & $\begin{array}{l}\text { The school's } \\
\text { application } \\
\text { was rejected. }\end{array}$ & $\begin{array}{l}\text { High Court: Application } \\
\text { was successful but the } \\
\text { case was reviewed and the } \\
\text { school's application was } \\
\text { dismissed. } \\
\text { ScA ruled in favour of the } \\
\text { school: } \\
\text { * department's decision to } \\
\text { withdraw the function of } \\
\text { the governing body to } \\
\text { determine the language } \\
\text { policy of the school was } \\
\text { set aside. } \\
\text { appointment of interim } \\
\text { committee to determine } \\
\text { the language policy of } \\
\text { the school was set aside. } \\
\text { *ecision of interim } \\
\text { committee to amend the } \\
\text { language policy of the } \\
\text { school was set aside. } \\
\text { cc: } \\
\text { * Governing body does not } \\
\text { have the exclusive power } \\
\text { to determine the } \\
\text { language policy of the } \\
\text { school - it is shared } \\
\text { between the Minister and } \\
\text { the governing body. } \\
\text { * Court ordered that the } \\
\text { school must review its } \\
\text { language policy and } \\
\text { report back to the court. } \\
\text { * Department must report } \\
\text { back to the court "setting } \\
\text { out the steps it has taken } \\
\text { to satisfy the likely } \\
\text { demand for an English or }\end{array}$ \\
\hline
\end{tabular}




\begin{tabular}{|l|l|l|l|}
\hline Middelburg & Mikro & Seodin & \multicolumn{1}{c|}{ Ermelo } \\
\hline & & & $\begin{array}{l}\text { parallel-medium high } \\
\text { school in the Ermelo } \\
\text { district, as well as on the } \\
\text { situation at other high } \\
\text { schools in the area". }\end{array}$ \\
\hline
\end{tabular}

\section{CONCLUSION}

A child's constitutional rights may be violated and dishonored in different ways in the educational environment, and the question is whether South Africa meets its constitutional and international obligations with regard to mother-tongue education.

This is not an easy question to answer, since there are several stakeholders who must work together in order to give effect to the right to a basic education, and more specifically the right to receive education in the language of a person's choice. Firstly, a culture of awareness, consciousness and responsibility among all the relevant stakeholders concerned, is required in order to make the provision of mother-tongue education easier. This includes cooperation between the state, education authorities, school governing bodies, educators, parents and learners. Secondly, it is also important that all stakeholders accept their responsibility and duty to observe the rights of all learners.

The Constitution is a comprehensive document which clearly sets out all the basic democratic values and principles to be incorporated into the South African school system. However, the transformation of school education and the effective provision of mother-tongue education are still slow and unsatisfactory. The transformation of school education is therefore a slow and ongoing process "which takes place within the wider socio-economic and political realities of the country - realities which have often hamstrung or prevented the achievement of educational ideals". ${ }^{113}$

With regard to international policies (international instruments), the basic principles and values of the right to education and the provision of mothertongue education, are also clearly set out. It is therefore submitted that in South Africa, the right to a basic education and the right to receive education in the language of a person's choice, will be realized only "to the extent that the state and all other stakeholders are capable of providing the necessary infrastructure in terms of facilities and human resources, and an effective system in terms of discipline and good governance". ${ }^{114}$

\footnotetext{
${ }^{113}$ Malherbe "The Impact of Constitutional Rights on Education" in Boezaart (ed) Child Law in South Africa (2009) 474.

114 Malherbe in Boezaart (ed) Child Law in South Africa (2009) 419.
} 